\title{
Some Remarks on Mr. Takahashi's Paper on the Identity of Ustilago virens Cooke and Ustilaginoidea Oryzæ Brefeld.
}

\author{
By
}

\section{J. Omori.}

In the last number of this Magazine Mr. Takahashi of Sapporo described the morphology of Ustliago virens together with a new species of Tilletia parasitic on the rice-plant, and expressed his views on the identity of the former with Ustilaginoidea Oryza recently described by BREFELD. As regards his new species we have nothing to say, but as to the opinion that Ustilago virens is identical with Ustilaginoidea Oryzce I think it requires some further proof.

First of all, let us examine this question. Although Mr. Takanashi describes the resemblance of morphological characters of these two fungi, they are proved to be quite different when we examine the mode of their germination. Thus the germinating spores of Ustilago virens produce in a culture solution sporidia which multiply by budding like yeast without intervension of promycelium(1) as it is the case with Ustilago olivacea, ${ }^{(2)}$ while the germinating spores of Ustilaginoidea Oryzce produce, according to BREFELD, hyphæ which bear conidia. ${ }^{(3)}$ Thus in spite of the close resemblance of the other morphological characters the difference regarding the mode of germination is so great that we need no further discussion about this question. So the fungus hitherto referred to Ustilago virens Cooke by Messrs. Tanaka, HorI, and Takahashi proves not to belong to the Ascomycetes like Ustilaginoidea, but to be a distinct species belonging to the Ustilaginece.

As regards the structure of the sporiferous body Mr.' Takahashi described at full length the three spore-producing outer layers and the central medulla composed of a sclerotioid mass of hyphal weft;

(1) The details of this development will be soon published in the "Bulletin" of the College, of Agriculture, Imperial University.

(2) Brefeld, Bot. Untersgn. üb. Hefenpilze, Heft V, Taf. X, Fig. 12.

(3) Brefeld, Bot. Cent. Bd. LXV, No. 4, 1896. 
but besides there is another important structure which must not be overlooked. I mean the envelope or the wall of the compound sporophore which covers at first the whole spore-masses and remains attached after its rupture, forming a crisped thin membranaceous pieces near the husks of the deformed grain (Fig. A). This wall is comparatively thick and composed of many layers of branched hyphæ running parallel to one another and forming here and there $\mathrm{H}$-shaped connections as shewn in the annexed figures (Figs. B, C). These hyphæ are hyaline, distinctly septate, and have a wide lumen; of these, those situated near the surface consist entirely of sterile filaments, and those running near the spore-producing layers still retain their power of producing rudimentary spores (Fig. C). The sporogenous hyphæ formed between this wall and the central medulla are of very sticky nature, as it is usually the case with many other Ustilaginees, owing to a thick gelatinous wall; they have no distinct septum, have a very narrow lumen as shewn in Fig. D, and are gradually used up to form spores so that at maturity only heaps of spores remain. We cannot find any such permanent hyphæ as shewn in Mr. TaKaHAshi's figure among the ripe spores of the outermost layer. In short, as regards the structure of the sporogenous hyphæ, more especially as to the mode of spore-formation, his statement is not correct, his figures which shew different stages of spore-formation being decidedly erroneous; we can find in the true sporogenous hypha neither septa nor sterigmata resembling those of his figure.

On the other hand, his figures correspond pretty closely to the spore-bearing hyphæ found in the inner layers of the wall covering the spore-masses previously mentioned; but here the longer projections found on the lateral wall of the filament do not represent sterigmata at all, but only broken pieces of the transverse projections of $\mathrm{H}$-shaped connections (Fig. B).

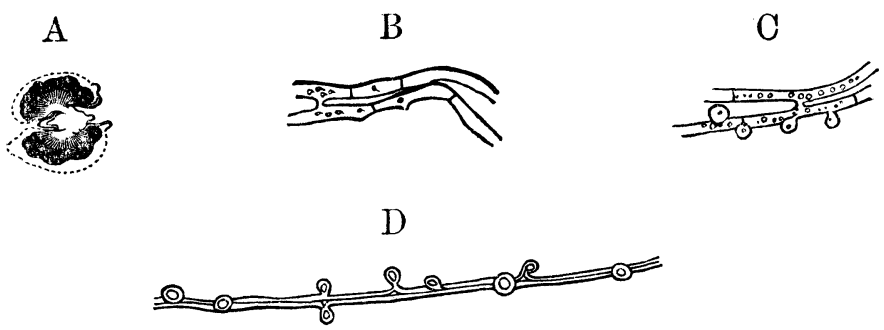


Now let us turn to the consideration of the systematic position of the present species. From the lack of authentic specimens we are by no means sure that the fungus in question is identical with Ustilago virens of Cooke, but the main characters of this species agree so closely with the description of his species that we may consider them to be probably identical. On close examination, however, we are led to the conclusion that the present species does not belong to Ustilago. Professor ShiraI of our College is of opinion that it may be safely placed in the genus Spluacelotheca first founded by $\mathrm{DE}$ BARY. ${ }^{1}$ Indeed, the presence of the permanent stroma, of the central columella, and of the enveloping wall, are the chief characters which separate this genus from all other genera of this order; and the present species possesses all these characters. The mode of germination differs a little from the typical fungus described by $\mathrm{DE}$ BARY, but the generic characters may reasonably be modified so as to comprise this second species. And so this fungus may be called "Sphacelotheca virens."

Botanical Laboratory of the College of Agriculture, Imperial University, March, 1896.

\section{Phanerogams of Shōnai.}

(Continued from No. 108)

By

\section{T. Kawakami.}

\section{莊內産顯花植物（前號，續平）川上瀧彌}

Piperaceæ.

630. Saururus Loureirii, Decne. ハンゲシャウ 鼠ケ關 (金峯山麓ニモ 產不)

631. Houttuynia cordata, Th. ドクダミ（ドクタビ方言）松嶺

(1) de Bary, Vergl. Morph. u. Biol. d. Pilze, etc., 1884. 